\title{
Rehabilitation and Nursing Homes with Elderly and Homeless Population, Lessons not only for Physiotherapy but also for Epidemiology?
}

5. Subramanian (Selvaraj Subramanian)3), M. Belovicova (Maria Belovicova)2,

P. Vansac (Peter Vansac)2, M. Palun (Miroslav Palun)2, L. Radkova (Libusa Radkova)2, J. Otrubova (Jana Otrubova)2, R. Vlcek (Robert Vlcek)2, J. Benca (Juraj Benca) ${ }^{4}$, M. Olah (Michal Olah)2 ${ }^{2}$ L. Matulnikova (Ludmila Matulnikova)2, M. Sramkova (Maria Sramkova)2 , P. Cmorej (Patrik Cmorej)2, V. Krcmery (Vladimir Krcmery), ${ }^{2}$ A. Shahum (Andrea Shahum) ${ }^{1}$

${ }^{1}$ University of North Carolina at Chapel Hill, NC, USA

Original Article

2 St John Neumann Institute SEU and St Lesley College, Pribram, CZ

3 SEUC MSc. Program, Kuala Lumpur, MY

${ }^{4}$ IGAP Vienna

\section{E-mail address:}

ashahum@med.unc.edu

\section{Reprint address:}

Andrea Shahum

UNC Chapel Hill, NC, USA

Source: Clinical Social Work and Health Intervention

Volume: 9

Issue: 3

Pages: $64-66$

Cited references: 4

\section{Reviewers:}

Johnson Mavole-jmavole@cuea.edu

Daria Kimuli - pechacova.daria@gmail.com

\section{Key words:}

Nursing homes. Elderly. Multi-resistant pathogens.

\section{Publisher:}

International Society of Applied Preventive Medicine i-gap

CSWHI 2018; 9(3): 64 - 66; DOI 10.22359/cswhi_9_3_08 (c) 2018 Clinical Social Work and Health Intervention

\section{Abstract:}

Background: Infections occur frequently in nursing home residents, mainly pneumonia, UTI and SSTI, usually requiring empirical 
antimicrobial treatment in an hypo-immune population, which contribute to the increasing frequency of antimicrobial agent-resistant organisms in nursing homes.

Patients and methods: We did oropharyngeal swabs of residents of long-term facilities to detect their potential contamination with resistant pathogens in three nursing homes in Bratislava.

Results: Multi-resistant pathogens were recorded in total of 71 clients, but only $5(10 \%)$ were positive for gram-negative bacteria, however, in all, multi-resistant bacteria/yeast were obtained.

Conclusions: Monthly surveillance cultures, but also admission cultures, not only rectal, but also from respiratory tract are advisable.

\section{Introduction}

Rehabilitation and nursing homes are increasing in numbers, both in Europe and in US due to the risen life expectancy. Infections occur frequently in nursing home residents. The most common infections are pneumonia, urinary tract infection, and skin and soft tissue infection (SSTI). Aging-associated physiologic and pathologic changes, functional disability, institutionalization, and invasive procedures and devices all contribute to the high occurrence of infection. Antimicrobial agents used in nursing homes are usually empiric. All of these factors contribute to the increasing frequency of antimicrobial agent-resistant organisms in nursing homes.

\section{Patients and Methods}

In this pilot one-day point of prevalence study we did oropharyngeal swabs of 72 residents of long-term facilities to detect their potential contamination with resistant pathogens. Study was conducted on 21 st August 2018.

\section{Results}

Multi-resistant pathogens were recorded in 3 facilities with a capacity of 22, 24 and 25 clients, but only $5(10 \%)$ were positive for bacteria, however, in all, multi-resistant bacteria/yeast were obtained. In one of the last issues of Lancet (2), the authors highlighted the increase of parasitic infections among elderly residents in a nursing/rehab facility. There are little data on studies for elderly/homeless or nursing facilities on colonization with multi-resistant pathogens. Everybody however, will expect more gram-negative bacilli (Enterobacteriaceae) or Enterococci due to the decreased hygiene and morbidity. We have observed multi-resistant streptococci (MRSA) and azole-resistant Candida spp., what is a surprising finding in this group of hypo-immune patients.

\section{Conclusion}

MRSA and fluconazole-resistant Candida spp. were the major pathogens of the respiratory tract of hypomobile elderly residents of rehabilitation/nursing homes in Bratislava. Therefore, not only monthly surveillance cultures, but also admission cultures, not only rectal, but also from respiratory tract are advisable.

\section{References}

1. WHO ANNUAL REPORT (2016) Life expectancy worldwide. WHO 2016

2. BELOVICOVA M, LISKOVA A, HRINDOVA T et al.: (2017) Low Prevalence of MRSA in Physiotherapy and Gym Facilities 
in a Greek Refugee Camp. Clinical Social Work and Health Intervention Vol. 8 No. 22017.

3. KHALED I, ALI HAJ P, KRCMERY V, KALATOVA D, GALLOVA A, BAK T, SCHUMMAN I, DUDOVA Z, ZOLLER K, REITH B, OBTULOVIC M, OLAH M, HRINDOVA T, BELOVICOVA M (2017)
Spectrum of infections in physiotherapy and rehabilitation ward for war victims and veterans from Iraq and Syria (short note). Clinical Social Work and Health Intervention. 8. 26-28. 10.22359/cswhi_8_2_05.

4. ALI HAJ P et al (2016) Are migrants from Middle East carriers of multi-resistant bacteria? Clinical Social Work and Health Intervention Vol. 7 No. 320162. 